\title{
THE PROGRAM EVALUATION OF THE IMPLEMENTATION OF PRODUCTIVE SKILL COMPETENCY TEST IN SMK NEGERI 3 SINGARAJA
}

\author{
Nyoman Santiyadnya \\ Electrical Engineering Department of Education, Faculty of Engineering and Vocational, \\ Ganesha University of Education, Jalan Udayana 11 C, Singaraja 81116 \\ santiyadnya@yahoo.com
}

\begin{abstract}
The objective of this study is to evaluate the effectivity of the implementation of skill competency test in SMK NEGERI 3 Singaraja. The data in this study was collected by interview, observation, document study and also questionaire. The respondents which were used to collect the data in SMK Negeri 3 Singaraja were the headmaster, vice headmaster and the leader of each skill competency. Meanwhile, to get the data about graduates professionality, the respondents were the students who graduated from SMKN 3 Singaraja in the academic year of 2011/2012. This program evaluation use CIPPO model. The data as the result of interview was collected, then it was reduced to get the conclusion. The result of this study shows that the implementation of skill competency test in SMKN 3 Singaraja viewed from the context, input, process and product has been done well. The graduates professility is in the level of less to really professional.
\end{abstract}

Keywords: program evaluation CIPPO model, skill competency test, graduates professionality.

Vocational High School is a school that educates students to always be able to follow the development of science and technology, is able to live independently, and able to develop their knowledge through higher education. This is similar to the President of the Republic of Indonesia Regulation Number 19 of 2005 Article 26 Paragraph 3 stipulates that the competency standards in secondary vocational education unit aims to improve intelligence, knowledge, personality, ahklak noble, and skills to live independently and follow further education according with vocational. Therefore, it can be said that the vocational high school (SMK) is a high school that aims to produce graduates become skilled workers and professionals in the field in accordance with a program that is always insightful expertise in the future and in accordance with market needs. For that vocational graduates should be able to adapt to the development of science and technology (Science and Technology). Meanwhile, the Law of the Republic of Indonesia Number 20 Year 2003 on National Education System loaded the vision, mission, function, and purpose of national education, and the national education development strategy to achieve quality education, relevant to the needs of society, and competitive in the global life .

The opinion of some experts on the evaluation dikutif by Fernandes (1984: 1), namely: (1) Tyler argues that the process of evaluation is to determine whether the purpose of education is to be realized; (2) Cronbach and Stufflebeam argue that the evaluation is to provide information for decision making; (3) Joint Committee stated that the evaluation is a systematic investigation to identify the weaknesses and strengths of an object. 
In order to measure the achievement of the vision, mission, purpose schools, and curriculum with a comprehensive evaluation, one of the components of program evaluation is productive skills competency test. According to Olivia as copied by the Development Team Basic Course Curriculum Development and Learning (2011: 108) that the evaluation is a tool to determine what decisions need to be developed and to provide basic effects develop. Competence in vocational skills so always follow the development of competencies necessary to test to determine student mastery of the competency skills.

Productive skills competency test program is carried out against the assessment productive training through practice exams. Implementation of the program of productive skills competency test is strongly influenced by the facilities and infrastructure, the school environment, the role of teachers and principals, and the involvement of external parties. During this test program competency skills in SMK 3 Singaraja reported to have gone well, but in reality there are many graduates of SMK Negeri 3 Singaraja who have not been able to work in accordance with its competence. According Koyan (2012: 73) states that competence is an ability that can be done by learners which includes knowledge, affection or attitudes and behaviors. Knowledge possessed by graduates of SMK Negeri 3 Singaraja average is good, it can be seen from the test of competence which are the value range of 8.21 up to 9.65 value. But in terms of attitude and behavior is still lacking so impressed that graduates of SMK Negeri 3 Singaraja still much less professional. According to Gilley and Eggland as copied by Karsidi (2005: 8) defines a profession as a field of human endeavor is based on knowledge, skills and experience which the perpetrators needed by society. This definition includes the following aspects: a. particular science, b. application capabilities / skills, and c. relating to the public interest.

Competency skills are closely related to talent. Because when gifted students in the competency skills would be very easy for him to learn these competencies. This is consistent with the theory of giftedness according to Renzulli and his colleagues as copied by Munandar (2004: 24), a 'three-ring conception' which states that the three main characteristics is the criteria (requirements) is the link between giftedness: above general ability average, creativity above average, and binding themselves to the task (task commitment is quite high). While the students who do not have the talent at the skill competence, competence mastery will take a long time. This happens because the students need time to construct themselves. Thus it can be said that the provision of continuous training to students, can improve students' mastery of skills competency.

Based on the conceptual and empirical studies above, research on the evaluation of the productive skills competency test program at SMK Negeri 3 Singaraja need to be implemented, so it can know the effectiveness of productive skills competency test programs that have been implemented in SMK Negeri 3 Singaraja. 


\section{METHOD}

Evaluation study is an evaluation of the program describes the implementation of productive skills competency testing program for students of SMK Negeri 3 Singaraja which has lasted over the years, providing input in order to improve the weaknesses that are owned, as well as to improve the quality of productive skills competency test for vocational students in future. In detail, the objectives of this study are as follows: (1) describe the rational context of the implementation of skills competency test in SMK Negeri 3 Singaraja which took place during this time; (2) describe the role of each input component implementation skills competency test in SMK Negeri 3 Singaraja; (3) describe the process of implementation of skills competency test in SMK Negeri 3 Singaraja; (4) describe the results that have been achieved during the implementation of skills competency test in SMK Negeri 3 Singaraja; (5) describe the impact of the implementation of productive skills competency test to graduate professional SMK 3 Singaraja, in terms of the percentage of graduates who work in business and industry, working independently, and continued his studies, as well as the graduate work ethic.

Criteria used in evaluating the competency test program at SMK Negeri 3 Singaraja is (1) competency test can be carried out in accordance with applicable policies, (2) the support of facilities and infrastructure, teachers involved have been educated S2, the involvement of external parties, (3) the instruments used, and the assessment process in accordance with ketentua BSNP, and (4) all students passed the competency test with a value greater than 75 .

In this research, an evaluation of skills competency test on the ninth of the study program is implemented. implementation skills competency test conducted at SMK Negeri 3 Singaraja should be adjusted to the prevailing curriculum at SMK Negeri 3 Singaraja, facilities and infrastructure available, the principal's commitment to implement the skills competency test, teachers' commitment to support the implementation of the competency test expertise, objectivity parties external to the assessment, as well as the readiness of students in skills competency test program.

This study is the evaluation of a program that uses the model CIPPO. CIPPO evaluation model used to evaluate the implementation of the skills competency test in terms of context, input, process, and product as well as its impact on professionalism SMK graduates 3 Singaraja (CIPP-O). This study uses a regressive models, which begins with a search of vocational graduates, and then traced back to find the relationship between professionalism graduates with skills competency test execution when the graduates join the competency test, after it resumed searching the relationship competency test execution expertise to the component context, input, processes and products.

To get the data associated with professionalism SMK graduates 3 Singaraja in the world of work done qualitatively by conducting interviews, and direct observation to superiors, peers at institutions of vocational graduates are working. Evaluation of policy-related context to the 
achievement of goals and objectives of the competency test, which includes: (1) the vision and mission of CMS; (2) vocational goals; (3) geographic location. Evaluation aims to identify the inputs, measuring systems, and designing implementation strategies. Input which is supporting the implementation of quality test of competence include: curriculum, students, teachers, external parties, school management, facilities, and school environment. The evaluation process can be done through interviews with implementing competency testing expertise. Product evaluation is to analyze the level of vocational students after graduation following skills competency test. How the contribution value of the skills competency test students' final grades. In this study also observed the impact of the implementation of the skills competency test which is a form of professionalism outcome 3 Singaraja SMK graduates in business and industry.

\section{RESULTS}

Based on the results of interviews with executive skills competency test in SMK Negeri 3 Singaraja, data showed that all study programs implementing competency testing expertise. In Action Reviews competency test skill, SMK Negeri 23 Singaraja implement competency skills test models. Competency test skills competency test skill in question is a national of the National Education Standards Agency (BSNP) and skills competency test conducted by professional certification agencies (LSP). In the implementation of the National Education Standards skills competency test refers to the UKK BSNP guidelines. While the implementation of the competency test skill of professional certification agency carried out in collaboration with a certification body that has the appropriate skills to each competency skills. As the expertise competencies Computer Engineering Network (TKJ) in collaboration with CISCO, Multimedia in cooperation with the Community Roots of Science, Construction Engineering building (TKB) in collaboration with the Association of Indonesian Construction Experts (ATAKI), Techniques Audio Video cooperate with AKARI, in collaboration with the Institute of Engineering Machinery Professional Certification Metals and Machinery Indonesia (LSPLMI), and in collaboration with the Architecture Engineering INKINDO Bali.

Implementation of skills competency test has been very consistent with the vision and mission of SMK Negeri 3 Singaraja because the purpose of the implementation of skills competency test to find out how much students master the competencies of expertise while on a mission SMK 3 Singaraja especially number 3 stated that the mission of SMK Negeri 3 Singaraja is "generating graduates who are skilled, independent and noble character "and the mission number 4 stated that the mission of SMK Negeri 3 Singaraja is" Engaging with stakeholders at regional, national, and international. So that when viewed from the vision and mission of SMK Negeri 3 Singaraja, the implementation of the skills competency test is in conformity with the vision and mission. Meanwhile, if the terms of vocational goals, implementation skills competency test is also aligned with 
the goals of SMK Negeri 3 Singaraja. When viewed from the geographical position of SMK Negeri 3 Singaraja, skills competency test execution can be implemented either as material / equipment for the purposes of the implementation of skills competency test can be directly delivered to each workshop and the steepness of the road to the school is less than 450 Implementation of skill competency test is not disturbing the environment around the school and surrounding environment also does not interfere with the implementation of skills competency test in SMK Negeri 3 Singaraja.

The results of observations conducted at SMK Negeri 3 Singaraja obtained the following data: (1) That the implementation of skills competency test in SMK Negeri 3 Singaraja always refer to the guidelines published by the National Education Standards; (2) The vision and mission of SMK Negeri 3 Singaraja introduced to the academic community by setting a vision and mission in the driveway SMK Negeri 3 Singaraja and public places frequented by the community of SMK Negeri 3 Singaraja; (3) The distance of the school to the highway about 10 feet, but the theory classrooms, workshops, and other spaces used for teaching and learning process is rather far into the surrounding environment so it does not interfere with school. The noise that occurs on the highway not to interfere with teaching and learning process in SMK Negeri 3 Singaraja.

In the study documentation, while the observed documents are the documents relating to the implementation of skills competency test in SMK Negeri 3 Singaraja primarily associated with the context. To facilitate the implementation of skills competency test, SMK Negeri 3 Singaraja cooperation with business and industry and LSP. Cooperation is tied up in the form of an MoU. Thus it can be said that the school policy related data available is incomplete (SL). Based on the results of questionnaires related to the implementation of skills competency test in SMK Negeri 3 Singaraja comparison of results obtained with mean $\mathrm{T}$ scores on each sub-component in the component context, where in all the sub-components of the T-score values greater than the mean.

By using the response scale test showed that all the sub-components of positive status, thus it can be concluded that the positive status of the component context. So based on the results of questionnaires may be concluded that the terms of the context of the implementation of skills competency test in SMK Negeri 3 Singaraja is going well. So in terms of context, based on interviews, observation, document study, and questionnaires can be concluded that the implementation of a competency test in SMK Negeri 3 Singaraja can be done well.

Meanwhile, from the results of interviews with executive skills competency test in SMK Negeri 3 Singaraja, especially in terms of input data obtained related curriculum, students, teachers, external parties, and infrastructure. In a new student of SMK Negeri 3 Singaraja using 3 lines, namely poor track, track achievements, and track tests. Although there is a poor track, the admission of new students still consider the prospective student achievement owned. However SMK Negeri 3 Singaraja not implement an aptitude test to determine student competency skills, so that students are given the freedom to choose according to their interests 
competency skills. While the facilities and infrastructure owned SMK 3 Singaraja as support in the implementation of skill competency test was adequate. Based on the results of questionnaires related to the implementation of skills competency test in SMK Negeri 3 Singaraja comparison of results obtained with mean $\mathrm{T}$ scores on each sub-component in the component input.

Analysis of the component inputs on the sub-component is obtained that all positive status, thus it can be concluded that the positive status of the input component. So based on the results of questionnaires may be concluded that in terms of inputs, execution skills competency test in SMK Negeri 3 Singaraja is going well.

Results of interviews with the executive committee skills competency test in SMK Negeri 3 Singaraja data showed that in implementing competency skills test, the instrument used is an instrument that is issued by the National Education Standards that have a standard instrument. While the assessment form has also been provided by the National Education Standards. But in combining the value of teachers and external parties used the average value of the composition of $50 \%$ the value of teachers and $50 \%$ of the external parties. In addition to the national skills competency test, SMK Negeri 3 Singaraja also hold a competency test skill of the LSP, this is done in order to graduate SMK 3 Singaraja in addition to a diploma also have a certificate of competency expertise has gained the recognition of business/ industry. Examiners are involved in skills competency test in SMK Negeri 3 Singaraja is productive teachers who have at least 5 years of teaching experience. In the implementation of the skill competency test, teachers as testers testers II.Sedangkan I was assessors from business/industry and has a certificate as an assessor in the field of expertise

Based on the results of a study to document each skill competency data showed that the instruments used in the skill competency test in SMK Negeri 3 Singaraja is an instrument issued by BSNP complete the assessment form. While the involvement of relevant documents assessors as testers I and II teacher as examiner also documented in full. Based on the calculation results showed that all the sub-components of a positive status, thus it can be concluded that the positive component of the process status. So based on the results of questionnaires may be concluded that in terms of the implementation process skills competency test in SMK Negeri 3 Singaraja is going well.

Values obtained by the students in the skills competency test, all students passed. Meanwhile, judging from job after graduation, most graduates choose to continue their studies, most work in the business/industry, and only a small proportion who choose entrepreneurship. This happens according to the testimony of the respondent because almost all the graduates have not been willing to take risks that might occur if entrepreneurship despite their competence is very adequate. So impressed that SMK graduates 3 Singaraja risk management has not been able to do against him. Most graduates of SMK Negeri 3 Singaraja who choose to continue their studies Bali State Polytechnic as a place to gain knowledge, 
but there is also continued his studies at the University of Education Ganesha. SMK graduates 3 Singaraja not many people dare to continue university studies to favorites such as UGM, UI, ITB, and ITS. This happens not because of SMK Negeri 3 graduates are incompetent, but simply because cultures for most of the Balinese people who tend not to allow their children to be away from family.

The results of a study conducted by researchers to document each competency skills, data showed that the value of the average student ranged from 8 to 9 Specifically skill competency test value of each competency skills as shown in the following table.

Table 1. Skill competency test (UKK) value in the range of SMK Negeri 3 Singaraja Academic Year 2011/2012

\begin{tabular}{clc}
\hline No. & \multicolumn{1}{c}{ Skill Competencies } & UKK Value Range \\
\hline 1 & Computer Networking Engineering & $8,2-9,2$ \\
2 & Multimedia & $8,3-9,0$ \\
3 & Audio Video Engineering & $8,2-9,5$ \\
4 & Electrical Engineering & $8,5-9,6$ \\
5 & Engineering & $8,5-9,3$ \\
6 & Otomotif Engineering & $9,0-9,5$ \\
7 & Teknik Konstruksi Bangunan & $9,1-9,6$ \\
8 & Architecture Engineering & $8,21-9,65$ \\
9 & Welding Engineering & $8,6-9,5$ \\
\hline
\end{tabular}

Comparison with mean $\mathrm{T}$ scores on the component products based questionnaire data related implementation skills competency test in SMK Negeri 3 Singaraja obtained results. Based on the calculation results showed that the positive status of the product components. So based on the results of questionnaires may be concluded that in terms of product implementation skills competency test in SMK Negeri 3 Singaraja is going well. When the category of all components of the competency test either context, input, process, and products included in the quadrant above illustration Glickman obtained as follows.

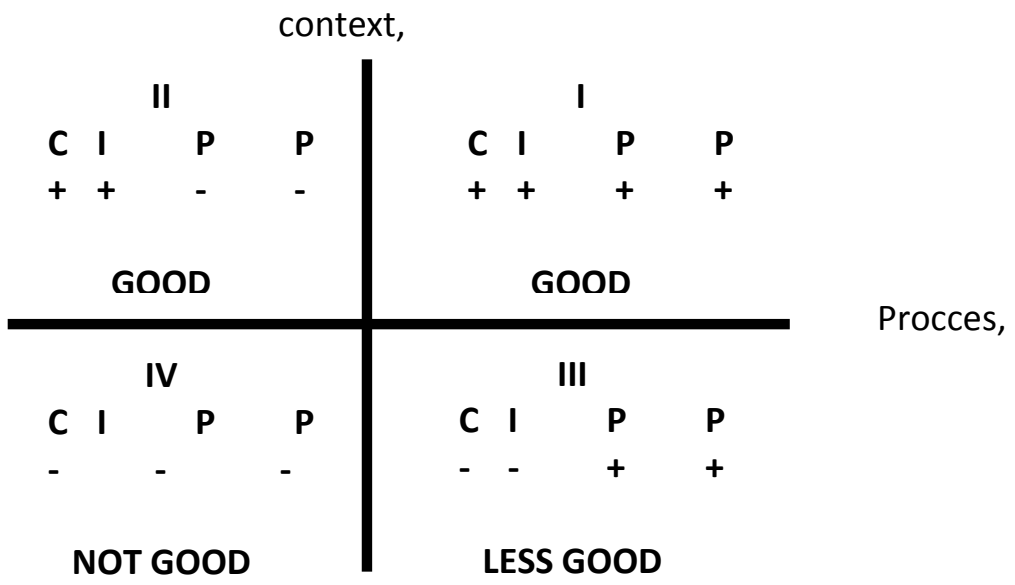

Picture 1. Competency Test Execution Quality in SMK Negeri 3 Singaraja when viewed from quadrant Glickman 
SMK graduates 3 Singaraja have sufficient competence when entrepreneur-ship. This is evident from the results of interviews with respondents who graduate competency skills Techniques Audio Video (TAV), at first (since class XI) have started small entrepreneurs to receive television service but due to high interest and supported by talent, now his business has entered to the computerized world. Meanwhile, based on interviews with the boss or colleagues SMK graduates 3 Singaraja work obtained information that the working attitude of SMK graduates 3 Singaraja very good. This means that all assigned tasks can be completed with as best and as quickly as possible. SMK graduates 3 Singaraja was also very creative in making innovation at the time of doing his work.

\section{DISCUSIONS}

The result of data above, both data from interviews, observation, document study, and questionnaires known that the implementation of skills competency test in SMK Negeri 3 Singaraja both in terms of context, input, process and products include both categories. On the other hand from the results of the questionnaire can be concluded that professionalism SMK graduates 3 Singaraja at the level of less professional until very professional.

1. Implementation of Competency Test in SMK Negeri 3 Singaraja in terms of context

It appears from interviews, observation, document study, and questionnaires that in terms of both policy context, objectives, and geographic location are already performing well. However, some teachers lack an understanding of guidelines for the implementation of skills competency test in SMK Negeri 3 Singaraja. This is evident from the results of the questionnaire on the sub-components of the policy outcome T score of 8 people were negative status of 66 respondents. This indicates that there are 8 respondents who do not understand the policy used in the implementation of skill competency test in SMK Negeri 3 Singaraja. Skill competency test guidelines published by the National Education Standards because usually only observe chairman of competency skills.

2. Implementation Skills Competency Test in SMK Negeri 3 Singaraja in terms of input

Implementation of skills competency test in SMK Negeri 3 Singaraja when viewed in terms of the input has been progressing well in accordance with the results of interviews, observation, document study, and questionnaires. When viewed in terms of the curriculum, teachers, facilities and infrastructure, environmental conditions are very good schools so that the implementation of skills competency testing can take place properly. Then from the component assessors, all existing competency skills in SMK Negeri 3 Singaraja has been used externally as an assessor in skills competency test. Even external parties is not only derived from business/industry but there are professional certification agencies (LSP).

At the student component of some problems because not all students have the appropriate talent with competencies that occupied expertise. 
According to the theory of competency, if someone has had the ability to deal with situations and circumstances in their work, this person can be said to be competent. According to the theory of social construction, the individual cognitive work to interpret the world of reality that exist due to the social relations between the individual and the environment or the people around him. Individuals then build their own knowledge of reality is seen that based on the structure of pre-existing knowledge.

3. Implementation Skills Competency Test in SMK Negeri 3 Singaraja in terms of process

When viewed from the interviews and documents related to the implementation study skills competency test in SMK Negeri 3 Singaraja can be seen that in terms of the implementation process has been going well. Because the instruments used are instruments prepared by the National Education Standards. In terms of assessment, the form used is also using a standard assessment form from the National Education Standards. Meanwhile, in terms of testers, test skills competency in SMK Negeri 3 Singaraja has used an external examiner of business/industry and LSP.

4. Implementation Skills Competency Test in SMK Negeri 3 Singaraja in terms of product

The data results of research conducted with the document study showed that the range of skills competency test result values between 8.2 to 9.65, meanings that the mastery of skills competency SMK graduates 3 Singaraja very nice. Although student input performance is not too good, but if the student is able to construct himself well, can give good results as well. The competency test results can be achieved because the teacher tried to get students to construct himself so as to master the competencies expected. To achieve the above, the teacher always guides students in mastering their competence gradually until the student can master the competencies in accordance with the standards expected graduation.

5. Impact Implementation Skills Competency Test in SMK Negeri 3 Singaraja in terms of Professionalism Graduates

Results of interviews with graduates of SMK Negeri 3 Singaraja both advanced graduate studies, worked in the business/industry or government agencies, and graduate entrepreneurship competence is known that in SMK graduates 3 Singaraja very competent. This suggests that professionalism should SMK graduates 3 Singaraja is at the professional level until very professional. It turns out there are still problems related to professionalism SMK graduates 3 Singaraja although competency test execution expertise includes both categories, when viewed from the quadrant Glickman. Because based on the results of interviews there are some graduates who are not categorized as professional and less professional. Based on the interview data showed that the cause of no or lack of professional competence of graduates is partly because the skills are not in accordance with the interests and talents of the graduates. There are 3 things that cause a lack of professionalism expected of graduates of SMK Negeri 3 Singaraja as the impact of the implementation of skills competency test, namely: 1) lack of talent that was involved in the competency skills; 2) Low risk management; and 3) environmental influences. 


\section{CONCLUSION}

Based on the results of exposure studies, some conclusions can be formulated in accordance with the problems that were examined in this study as follows.

1. Implementation of skills competency test in SMK Negeri 3 Singaraja when viewed in terms of the context already performing very well and support is available for a very complete document. This is evident from interviews, observations, and studies document that the implementation of skills competency test in SMK Negeri 3 Singaraja is in accordance with government policy, especially BSNP, vision and mission and purpose of SMK Negeri 3 Singaraja.

2. Implementation of skills competency test in SMK Negeri 3 Singaraja when viewed in terms of inputs including both categories, because the curriculum used in SMK Negeri 3 Singaraja always adjusted to the development of science and technology and the needs of stakeholders. While the input of students, especially at the time of admission of new students has made the selection with three lanes (lanes poor, track achievements, and TPA lanes) but the new admissions aptitude test is not performed. Competency skills so that students choose according to their interests and not because of his talent. Facilities and infrastructure to support the implementation of skills competency test in SMK Negeri 3 Singaraja tersedian very complete with good condition. Availability of teachers in SMK Negeri 3 Singaraja is enough, but only about $10 \%$ are already S2 educated.

3. Implementation of skills competency test in SMK Negeri 3 Singaraja when viewed in terms of the process is in excellent because in addition to his skills competency testing process involving external parties of business/industry, process skills competency test was also carried out by the certification body. Instrument in the implementation of a competency test to use the instrument of the National Education Standards.

4. Implementation of skills competency test in SMK Negeri 3 Singaraja when viewed in terms of the product quite good because the products are already produced graduates who are able to master their competence but only a fraction are capable of self-employed, and most choose to continue their study of high teachership. This happens because the SMK graduates 3 Singaraja difficulty obtaining capital in addition to courage to bear the risk is still low.

5. The impact of the implementation of skills competency test to graduate professionalism, it appears that graduates of SMK Negeri 3 Singaraja at the level of unprofessional until very professional. The professional level is not based on interviews and observations that there are some 3 Singaraja SMK graduates are not capable of self-employed and work in accordance with their competence even when further studies are also not in accordance with their competence (automotive college graduates in Early Childhood Teacher Education / PGSD). But on the other hand, some graduates of SMK Negeri 3 Singaraja able to college while entrepreneurship competence. This happens 
because there are three factors, namely: lack of talent, not daring to risk, and the influence of the environment.

\section{REFERENCES}

Arikunto, Suharsimi. (2012). Dasar-Dasar Evaluasi Pendidikan. Jakarta: PT. Bumi Aksara.

Fernandes, H. J. X. (1984). Evaluation of Educational Programs. Jakarta: National Education Planning, Evaluation and Curriculum Development.

Joint Committee Educational Assessor. (1991). Ukuran Baku untuk Evaluasi Program, Proyek, dan Materi Pendidikan. Terjemahan Rasdi Ekosiswoyo. Semarang: Institut Keguruan dan Ilmu Pendidikan Semarang Press.

Karsidi, R. (2005). "Profesionalisme Guru dan Peningkatan Mutu Pendidikan di Era Otonomi Daerah”. Makalah. Disampaikan dalam Seminar Nasional Pendidikan Dewan Pendidikan Kabupaten Wonogiri, 23 Juli 2005

Koyan, I Wayan. (2012). Evaluasi Program Pendidikan. Singaraja: Universitas Pendidikan Ganesha.

Kunandar. (2011). Guru Profesional: Implementasi Kurikulum Tingkat Satuan Pendidikan (KTSP) dan Sukses dalam Sertifikasi Guru. Jakarta: Rajawali Pers.

Munandar, Utami. (2004). Pengembangan Kreativitas Anak Berbakat. PT. Rineka Cipta, Jakarta.

Tim Pengembang Mata Kuliah Dasar Pengembangan Kurikulum dan Pembelajaran. (2011). Kurikulum dan Pembelajaran. Jakarta: PT. Raja Grafindo Persada.

\section{Perundang-undangan}

Pedoman Penyelenggaraan Uji Kompetensi Keahlian (UKK) Sekolah Menengah Kejuruan (SMK) Tahun Pelajaran 2012/2013.

Peraturan Presiden Republik Indonesia Nomor 19 Tahun 2005 tentang Standar Pendidikan Nasional.

Undang-Undang Republik Indonesia Nomor 20 Tahun 2003 tentang Sistem Pendidikan Nasional. 